\title{
Serial murders: criminological profiles
}

\author{
Vincenzo Mastronardi, ${ }^{1}$ Giovanni Neri ${ }^{2}$ \\ ${ }^{1}$ Psychiatrist, Forensic Psychopathologist, Clinical Criminologist Sapienza University of Rome, Director of the \\ Criminology Master I Level Unitelma Sapienza Rome and Director of the Criminology Master II Level International \\ Studies University of Rome (UNINT); ${ }^{2}$ Attorney and Professor of Criminology at U.P.M., Milan, in charge of the Jus \\ Comparative \& Law - Sapienza University of Rome, Italy
}

\begin{abstract}
The present work embraces multiple aspects related to the theme of serial murder, which is essentially addressed by a criminological and personological perspective. Attention will be focused first on the serial killer figure, which will analyze both the intrapsychic peculiarities and the most intrinsic motivations behind the homicidal action as well as the more technical and specific aspects of the modus operandi and the signature that convey this kind of offenders. At the same time, a victimological overview will be developed, focusing on the preferential victims in this delinquent mode. The article will also highlight a categorization of serial killings based on the motive, as well as different classifications of the major types of serial killers identified by multiple authors. Finally, criminal profiling will be analyzed, deepening the role of the profiler in investigations and outlining the presumed personality of the offender, thus circumscribing the field of potential investigators with particular reference to US reality.
\end{abstract}

\section{RIASSUNTO}

Il lavoro qui presentato abbraccia molteplici aspetti relativi al tema dell'omicidio seriale, che viene essenzialmente affrontato da una prospettiva criminologica e personologica. L'attenzione, infatti, si concentrerà inizialmente sulla figura del serial killer, di cui saranno analizzate sia le peculiarità intrapsichiche sia le motivazioni più intrinseche alla base dell'azione omicidiaria, nonché gli aspetti più tecnici e specifici quali il modus operandi e la firma, che connotano questo tipo di autori di reato. Parallelamente verrà sviluppata una panoramica vittimologica, con focus sulle vittime preferenziali in questa modalità delittuosa. L'articolo porterà inoltre alla luce sia una categorizzazione degli omicidi seriali in base al movente, sia diverse classificazioni dei principali tipi di serial killer individuati da più autori. Infine si parlerà di criminal profiling, e sarà approfondito il ruolo che il profiler assume nelle indagini, delineando la presumibile personalità del reo, e circoscrivendo così il campo dei potenziali indagati, con particolare riferimento alla realtà statunitense.

\section{RESUMEN}

El trabajo presentado aquí abarca múltiples aspectos relacionados con el tema del asesinato en serie, que se aborda esencialmente desde una perspectiva criminológica y personológica. De hecho, la atención se centrará en la figura del asesino en serie, que analizará las peculiaridades intrapsíquicas y los motivos más intrínsecos de la acción homicida, así como aspectos más técnicos y específicos, como el modus operandi y la firma, que transmiten este tipo de delincuentes. Al mismo tiempo, se desarrollará un panorama vistimológico centrado en las víctimas preferenciales en este modo delincuente. El artículo también destacará una categorización de asesinatos en serie basados en el motivo, así como varias clasificaciones de los principales tipos de asesinos en serie identificados por múltiples autores. Finalmente, se tratará sobre la caracterización delictiva, y se profundizará el papel que el perfilador tomará en la investigación, delineando la presunta personalidad del delincuente y circunscribiendo así el campo de investigadores potenciales, con referencia particular a la realidad estadounidense.

\section{The serial killer: Introduction}

The serial murder is a peculiar species of multiple murder, (1) defined by specific characteristics associated with the personality attitudes of the killer and the operational modalities of the crime. The serial murder in fact shows a clear and conscious will to kill and the crimes follow each other in a pathological circuit, repetitive and usually regular. The homicidal modus operandi is also characterized using ritual practices, often brutal, of a constant type, through which the killer signs the committed crime (2). Sometimes the victims are identified with care and planning on the basis of the peculiar habits of life or recurrent physical and biological characteristics, which the killer associates a symbolic link, most of the times a sexual matrix, (i.e. organized serial murder), while in other cases the impulse to kill is uncontrolled and the resulting choice is distracted and random (i.e. disorganized serial murder) (3).

Often the serial crime is associated with sexual crimes. Now, if this is true in most cases, the erotic drive is not always the basis of the homicide choices: these in fact are the result of internal conflicts, which are affected by personal, environmental and relational factors, linked to past experiences and the previous life of the killer, a generally abused person, insecure, narcissistic and suffering from personality disorders.

This is not to mention that, besides the murderer individually understood, it can be considered as serial killer in a broad sense also the killer of war, criminals belonging to mafia associations 
or subversive terrorist, or again, all those who commit murders within diverted groups (Satanists, bullies etc..), not only to affirm their membership in the criminal community, but also to meet their homicidal impulses, under the protection of the belonging team (4).

To better and definitively clarify the intrapsychic peculiarities of the Serial killer, we can without doubt refer to the dual level of the superficial level in which we can find economic or mafia motives or warfare, but in fact, at a deeper level, the "homicidal orgasm" is always an expression of paranoid hypertrophy of the compensatory one, for the need to express the will of extreme supremacy and compensatory hypertrophy of the ego. Refer to the next section of the research results of Palermo, Mastronardi (2005), Mastronardi, De Luca (2015) and Mastronardi 2017.

\section{The serial murders classification}

The serial murder par excellence, immediately identified as such by the lay public, unaware of criminological forensic notions, is the one committed for sexual reasons. It is a crime full of symbolism, where the killer signed his crime branding the victim or still leaving marks of his action, sadistic or necrophilic (5).

But the range of crimes that can be traced back to the serial assassination is very wide and can be classified according to various types of criminal motive.

Can be traced back to the category, murders committed for the control of power, for euthanasia, for extremism - religious, political, economic or paramilitary - for erotomania or symbolic revenge. In these cases, the author is respectively motivated by delusions of megalomania (6), from the conviction to alleviate the pain of others, from the defense of his own ideas, from the permanent sexual arousal, and from the desire to avenge a hypothetical undergone wrong.

The killed is usually a person known to the killer, in these cases, as in the serial murders committed "for personal gain" - that is, to derive an economic benefit from the death of others - and "conflict" - that is, the violent composition of negative interrelations with the victim. Unlike what happens for situational murders, committed for mixed or irrational motive. Here, in fact, the crime stems from a murderer's state of panic, caused by mental or bipolar illness of the individual, which is driven to commit a crime for unknown and unidentified reasons.

In this hypothesis in fact, the victims are unknown to the murderer and randomly selected from people of different gender, ethnicity, social status or age.

Usually, the crimes are committed by a single author, who vents repressed fantasies of his troubled past through crime. But as well as individual murders we can also find killings done by a couple or a group of people.

The killer couple consists in most cases of two profoundly distinct personality: one dominant, which physically commits the crime, and the other-one, dismissed, conniving and unable to react.

The group killers on the other hand, is originated by the pathological partnership between several diverted people, who kill for political, racial or religious ideals, that is to honor rituals imposed by esoteric or satanic cultures. It 's the case of the sects, which sometimes places the serial crimes side by side to mass murder, and to racist groups, organized on a paramilitary basis and moved by a sick desire to exterminate antagonistic ethnicity, or to progressively eliminate from their country, and from the world in general, races which are considered impure. These are then joined by less organized groups, acting without an ideal base, but for the sole purpose to finalize their affiliation with diverted communities (the typical example is the youth gangs).

From a victimological perspective, there is a distinction between murders of men, women, children, couples or masses. The first ones are rather infrequent, due to the physical resistance that the male can oppose to his killer. Although recently there is an increase in crimes based on a homophobic matrix, and the killing of homosexuals among them. In fact, whoever of them does not accept his condition, sometimes acts with the will to purge the world from their fellows. Usually it is still a matter of sex maniac crimes, or connected to the difficult relationship with some rejected personal features, leading to kill those that indirectly allow these to emerge.

The serial murders of women and children are, on the other hand, the most common. The serial child killer, like the pedophile, exploits to his advantage the limited control ability of the child, lured and easily manageable. He usually kills moved from puerperal psychosis or, if it is a sex offender, to perpetrate his abuses and eliminate the victim witness. This is particularly true in the case of unknown children, lured online, less loyal to the pedophile compared to those molested within their own family, driven to conspiracy from shame, fear and physical proximity of their aggressor.

Similarly, the killer of women takes advantage of poor physical endurance of his victim, usually chosen between very young girls, older people or prostitutes. These last have a strong predisposition to the killing and represent the favorite victims of the serial killers, both for psychological reasons and mere opportunity. On the one hand, the killer, usually sexually disturbed and incapable of a healthy physical relationship, uses the prostitute as a tool to recovery his self-esteem or he aims to purge it from sin. On the other hand, he simply satisfies his killing instincts with a subject who's easy to lure and kill undisturbed in isolated places. Not to mention that the death of a prostitute is usually attributed to her exploiter, as it is usually hard to relate to a non-regular customer. Usually the killer, male, kills to reaffirm his manhood, to heal atavistic contrasts with the mother figure - replicating, such as the killing of women with similar psycho somatic traits - or just to get rid of the witnesses of its serial rapes.

The couples Killer usually pours its relational inability on people sharing intimacy in a secluded environment (8). The serial mass murderer kills to satisfy his delusions of omnipotence. It differs from the non-serial mass murder because, while the latter, once stakeholders are exterminated, he believes that its mission has fulfilled, so that in most cases it surrenders to the police or takes his own life, the serial killer persists in the killings, planning in detail the ways and means of escape.

Finally, there are murders of "mixed victimology", where the murderer doesn't target people with specific physical, biological or personal characteristics but simply satisfies, with regular time intervals, his indistinct needs to kill.

Ultimately to make it clear on the superficial and deep motivations, from the "English Dictionary of the Crime" of V. Mastronardi Armando Curcio Editore 2017 to which you can refer we can read: Following the examination of data on 110 serial murders, the FBI Behavioral Science section in 1990 came to elaborate five main types. In this classification, the following types of serial killers appear: visionary, missionary, hedonistic, power-oriented, luxurious.

The visionary type includes the authors of murders executed in response to the "voices" or "visions" solicitation, usually under the influence of so-called hallucinations-command; the 
hallucinating voice is that of God that incites them to the massacre, while visual hallucinations produce in some the feeling of being driven by strange appearances that identify as mighty entities or demons. This is evidently the consequence of genuine mental disorders such as paranoid schizophrenia or paranoid delirium disorder. In the first case, the crime is usually bizarre and poorly organized, while in the latter it is most likely to be executed in a planned manner.

The mission-oriented serial killer, as the same name suggests, claims to have a mission to do that usually comes from the belief that it needs to clean the world from people he considers undesirable (i.e. prostitutes, vagabonds or drug traffickers). This kind of serial killer is almost never psychotic, although sometimes his certainty is supported by paranoid dispersions, and he is not remorseful for his actions as he is convinced of a useful job for the good of society.

The hedonistic killer is the one that commits the murderous act to take pleasure. The act gives him a sense of enjoyment similar to the almost orgasmic emotion of the gambler when he bets and waits for the results.

1. The type of power control-oriented killer, as the name indicates, has the main purpose of its serial killings to exercise total control over another person and the supreme power to decide its destiny.

2. The lusty type is an individual who, because of deep unconscious or preconceived conflicts, tries to temporarily extinguish the anguish produced by these conflicts through the libidinous-obsessive-compulsive devastation, and sometimes ritualistic, of the life of another being, deriving not only sense of power, but also sexual gratification. In psychoanalytic interpretation one could think that the serial killer struggle is between the Es and the Super-I or, as Wilson suggests (A Criminal History of Mankind New York Carroll \& Graf (1984)] that the battle leads to supremacy of the tension on the ability of self-control of the killer.

This classification of the FBI, concerning the reasons for the act, was re-elaborated by George B. Palermo, Vincenzo M. Mastronardi, "Criminological Profile", Giuffrè Ed., 2005), and subsequently by Mastronardi (always reported in PalermoMastronardi 2005) on the stock of the hundreds of psychodynamic and psychobiographical folders examined in international archives (see R. De Luca 2001 "Anatomy of Serial Killer" Giuffrè 2001 and P. De Pasquali "Serial Killer in Italy" Franco Angeli 3 edition 2016). There are 11 types:

- The visionary serial killer

- The missionary serial killer

1. with social protection tasks

2. pseudo-religious

3. pseudo-political

4. pseudo-cultural

5. racial

6. sexological-moralist

7. of the social order

- The hedonistic serial killer

- The serial killer of power control

- Lust serial killer

Atypical variants:

1. The sadistic serial killer of sectarian ritualism

2. The sadistic serial killer member of the mafia
- The sadistic serial killer of war

As well as the mixed atypical variants:

- The serial-spree killer

- The serial bomber

- In the activities of diversification "of the object of aggression", which is able to cruelly but indirectly harm the human being through his artistic and material goods, we find:

\section{- L'art serial Killing}

Ronald and Stephen Holmes, in Serial Murder (Sage Publications, 1998), then proposed the following typology, differently articulated between men and women:

- Male serial killer types:

- Visionary

- Missionary

- Hedonist

- with libido disorder

- Risk-taking

- Seeking comfort

- Oriented to power control

Female serial killer types:

- Visionary

- Oriented to comfort

- Hedonist

- Oriented to power control

- Disciple

But, is there a common motivation that drives the serial killer to act? "[...] The paramount need of all serial killers, regardless of individual differences, is to experience a sense of omnipotence in their lives through the exercise of power and control over the victims".

\section{Investigation profiles: The use of the so called criminal profiling}

The scene of a serial crime is undoubtedly the visual mirror of the killer's mind. For this it is essential to reconstruct the personality of the offender to be able to prevent further homicidal actions and to attempt a quick capture.

In the United States, the use of the so called psychological or offender profiling, is the basis of any investigation into the crimes committed in a serial basis (9).

The task of the profiler is to trace the psychological-psychiatric description of an unknown offender, based on an autopsy response, of the information collected at the crime scene and any other relevant information to frame the personal conditions of stimulation and production of the fact by its potential type of author. He uses compared evaluation techniques assuming that every crime scene is, to use the definition provided by the operators of the Behavioral Science Unit of the FBI, "a classroom where the unknown suspect teaches investigators something about himself'. In other words, given that every criminal, first the serial killer, express his behavioral inclinations during the execution of the crime, the comparison of the results obtained from the analysis of the crime scene with the personal attitudes attributed to types of criminals already identified, allows to define the potential personality of the unknown author narrowing down the possible suspects in the case. Historically, the figure, which draws its character from physiognomy and criminology, 
was born and developed based on studies of Lombroso, founder of the criminal anthropology. The author in fact, in the famous work "The criminal man", reconnected the tendency to commit a crime to primitive abnormalities and biological degeneration inevitably influential on the personality and, analyzing various types of inmates, he classified the offenders in the known categories of the born criminal- not very evolved, easily identified on the basis of unique physical characteristics - of the sick criminal - suffering from obvious mental disorders - and the criminaloid, dedicated to crime because he is motivated by particular social or environmental circumstances. Along this path, the German criminologist Kretschmer studied the relationship between human personality, phenotype and crime classifying four biotypes: "lepsotomico or asthenic" - tall, thin, associated to crimes against property such as theft and fraud - "picnico" - short and fat person, with a predisposition to violence - "athletic" - with good muscle development, which is also prepared to violence - and "dysplastic" - with dysmorphic variety, can be associated with violent crimes or crimes against morality.

Further developments in the delineation of the profiler figure came also from victimology, which from the examination of the criminal behavior on the victim's body, would allow the deduction of the motives and guidelines of personality and modus opera In America in 1972 was born the Behavioral Science Unit - which operated until recently, in the National Center program for the Analysis of Violent Crime (NCAVC) - and a few years later, John Douglas and Robert Ressler released Crime Classification Manual, which contains the results of studies conducted by the FBI (10). Important impulses also came from the investigation of the criminologist David Canter who, in partial dissonance with the profiling model developed by the FBI, focusing almost entirely on the insights of the profiler, he formulated an alternative scheme of definition of the criminal type based on: interpersonal consistency- which highlights the canons for the victims selection; significance of time and place of commission of the offense; criminal career; characteristics of the author, and lastly, forensic awareness - that is, any possible concealment of physical evidence of the crime.

Currently, in the American Police Schools, the processing technique of a psychological profile is undoubtedly much appreciated, especially in the presence of serial or sexually connected murders.

In Italy, however, the use of criminal profiling is limited mostly to the single category of serial murder and the only police force who uses the profilers is the Analysis of Violent Crime Unit, which relies on the professionalism of the investigators, forensic psychologists and experts who assist the investigating bodies and juridical authorities (11). This is so because of the concerns expressed by several parties to give credit to an uncertain discipline, based on statistic and intuitive type data and are not always reliable and the difficulties of finding the most appropriate professional to trace the criminal profile of the offender: on one hand, the intuition of the criminal psychologist might be preferred, considering that he can understand well the pathological dysfunctions generating crimes which are similar to that perpetrated, and on the other hand, it could be considered preferable the use of statistical and experiential data in the identification of a potential culprit (12).

Anyway, going back to the specific criminological analysis of serial killers, in the reconstruction of the psychological profile, account must be taken of all the elements, constants and variables, recurring at the crime scene.

In fact, the type of the chosen victim, the position of the body, the murder weapon, the homicide modality, the presence of signs of depersonalization, torture or overkilling, do tell a lot about the murder criminogenic and the personal characteristics of its author. For example, the immobilization of the victim, the removal and concealment of the body, the alteration of the scene and the choice of prudent identifying methods, turn towards organized personality, cold and generally apparently well integrated into the social fabric. Conversely, the lack of interest in the scene cleanup and the killing of occasional victims denotes disorganization, anxiety, low IQ and emotional instability. Or, to higher degrees of sadism correspond, to a first approximation, chronic killers, with a strong experiential baggage, while less violated bodies are usually connected to "novice" killer.

The analysis of the scene must then be complemented by evaluation of any other relevant information, including, of course, the criminal career of the murderer and any possible history of psychiatric conditions. Always bearing in mind the importance of the killer fantasies and the symbols used.

For example, the bandage of the victim, as well as to avoid possible identifications, can reconnect to the will of depersonalize her, inhibiting her view. And so, the presence of signs or recurrent burns, may be the signature of the killer on the violated body.

Finally, regarding the processing steps of the profile, you can find more moments of investigation. First, let's catalog the finding of the inspections and forensic, ballistic (if possible) and toxicological examinations, and then we proceed to the reorganization and evaluation of the acquired data; and finally, the criminal profile is drawn, which is then modulated and corrected at the time of capture of the killer to be applied as a model to cases of similar type and gender.

\section{References}

AINSWORTH P.B., Offender profiling and crime analysis, Paperbach London, 2001.

BRUNO F., MARRAZZI M., Inquietudine omicida: $i$ serial killer analisi di un fenomeno, edizioni Phoenix Roma, 2000.

CANTER D., Criminal Shadows: inside the mind of the serial killer, Kindle Edition Londra, 1994.

CIAPPI S., Serial Killer, Franco Angeli ed. Milano, 1998.

D'ARIENZO A., Sulle tracce del killer, Fratelli Palombi Roma, 1999.

DE LUCA R., Anatomia del Serial Killer, Giuffrè Milano, 2001.

DOUGLAS J., Crime Classification Manual, J. Douglas, A. Burgess, A.G. Burgess and R.K. Ressler Ed. New York, 1992.

FORNARI U., BIRKHOFF J., Serial Killer, Centro Scientifico Editore Torino, 1996.

GARBESI M., I Serial Killer, Edizioni Theoria Roma, 1997.

HICKEY E.W., Serial Murder: An Elusive Phenomenon, New York, 1990.

HOLMES R., Profiling Violent Crimes, Thousand Oaks, Sage 1996.

HOLMES R., DE BURGER J., Serial Murder, Newbury Park, 1990

LAVORINO C., Analisi investigativa sull'omicidio seriale, Roma, 2000 e I Serial Killer: il movente, la vittima e l'azione omicidiaria, in Detective \& Crime, I-II, 1993.

MASTRONARDI V., Dizionario Italiano del Crimine capitolo 1: I serial Killer, Armando Curcio Editore 2017

MASTRONARDI V., DE LUCA R., I serial Killer. Il volto segreto degli assassini seriali: Chi sono e cosa pensano? Come e perché uccidono? La riabilitazione è possibile? Newton \& Compton Roma 2013. 
NORRIS J., Serial Killers, Anchor Books New York, 1988.

PALERMO G.B., MASTRONARDI V., Il profilo criminologico. Dalla scena del crimine ai profili socio psicologici, Giuffrè editore 2005.

PANELLA G., Serial Killer, Morgana Firenze, 1998.

PICOZZI M., ZAPPALA'A., Criminal profiling. Dall'analisi della scena del delitto al profilo psicologico del criminale, McGrawHill Milano, 2001.

RESSLER R., BURGESS A., DOUGLAS J., Sexual Homicide Patterns and Motives, Lexington Book Londra, 1988.

WILSON C., SEAMAN D., The Serial Killers: A Study in the Psychology of Violence, True Crime Londra, 1990.
Correspondence: Vincenzo Mastronardi.

E-mail: vincenzo.mastronardi@uniroma1.it

Key words: Serial Killer, criminal profiling, intrapsychic peculiarities, modus operandi, signature.

Parole chiavi: Serial Killer, profilo criminologico, peculiarità intrapsichiche, modus operandi, firma.

Palabras clave: Serial Killer, perfil criminológico, peculiaridades intrapsíquicas, modus operandi, firma.

Received for publication: 2 September 2016.

Revision received: 6 May 2017

Accepted for publication: 7 July 2017.

(C) Copyright V. Mastronardi and G. Neri, 2017

Licensee PAGEPress, Italy

Rivista di Psicopatologia Forense, Medicina Legale, Criminologia 2017; $22: 22-26$ 